\title{
Exploring the incidence and causes of cesarean Delivery : Partially Mixed Concurrent quantitative and Qualitative analysis from a Medical College
}

\author{
Ayesha Ahmad ${ }^{1}$, Fareha Khatoon ${ }^{2}$,Suman Nishad ${ }^{3}$, Saambhavi $^{4}$, Sonali Sonam ${ }^{5}$
}

\begin{abstract}
Background: India has seen a rise in the incidence of cesarean deliveries (CD) especially in the last decade. The present national average stands at $17.2 \%$, which if taken as a stand alone figure represents an almost ideal statistical measurement. However, the country has widespread regional variations in the $\mathrm{CD}$ rate, ranging from $4.4 \%$ to $35.9 \%$. Auditing individual $\mathrm{CD}$ rates by each institution, and exploring reasons for high incidence remains an essential component of maternal care. Aim of the study: The present study was done to find out the incidence of CD at our facility, compare it with the national average and explore reasons for high incidence of CD. Methodology: It is a partially mixed concurrent quantitative and qualitative study including retrospective analysis of one year data and filling up of questionnaire from resident doctors. Data extraction was done from Maternity Ward, for all women who delivered during the aforementioned period in our facility, including socio-demographic profile, number of births, mode of delivery, reasons for induction of labour and any complications during childbirth. Statistical analysis was done using appropriate tests. Results: A total of 621 deliveries were studied, out of which $44.6 \%$ delivered vaginally and 55.3\% had CD. Conclusion: The incidence of $\mathrm{CD}$ in the present study is $55.3 \%$. The main reasons for high incidence of $\mathrm{CD}$ are high risk pregnancies, previous $\mathrm{CD}$, fear of litigation and logistical delays in performing Category I cesarean section, prompting early decision for CD.
\end{abstract}

Keywords: Cesarean Delivery; Vaginal delivery; Incidence of Cesarean section; Maternal morbidity

Bangladesh Journal of Medical Science Vol. 21 No. 02 April'22 Page : 284-290 DOI: http://doi.org/10.3329/bjms.v21i2.58060

\section{Introduction}

Cesarean Delivery (CD) rate has seen an exponential rise in India in the last decade with the present national average standing at $17.2 \%{ }^{1}$. These numbers can be misleading because of the regional variations observed with differing rates in urban/ rural sectors, public/ private facilities, tribal and non tribal areas etc. In 1985, at the convention in Fortaleza, Brazil World Health Organisation (WHO) ${ }^{2}$ declared that a $C D$ rate higher than $10-15 \%$ was unjustifiable in any circumstance. Further, it emphasised a CD rate of 5 to $15 \%$ as a measure of optimum maternity

1. Dr Ayesha Ahmad, DNB [Obst. And Gynae], DGO, MNAMS, MRCOG, Fellow in Advanced Gynaecology Laparoscopy, Fellow in fetal medicine. Associate Professor, Dept. Of Obst. And gynae, Era's Lucknow Medical College and Hospital, Lucknow, 226003. Email: docayeshaahmad@gmail.com. M. 0091-8800807090

2. Dr Fareha Khatoon. MS [Obst. And Gynae], FMAS. Associate Professor, Dept. Of Obst. And gynae, Era's Lucknow Medical College and Hospital, Lucknow, 226003. Email: faarehak@gmail.com. M. 0091-98387774

3. Dr Suman Nishad.MS [Obst. And Gynae]. Assistant Professor, Dept. Of Obst. And gynae, Era's Lucknow Medical College and Hospital, Lucknow, 226003, Email: suman.nishad.1988@gmail.com. M. 0091-9451309930

4. Dr Saambhavi. MBBS. PG Trainee, Dept. Of Obst. And gynae, Era's Lucknow Medical College and Hospital, Lucknow, 226003. Email: shambhavi.dpsrkp@gmail.com.M. 0091-9810981439

5. Dr. Sonali Sonam. MBBS. PG Trainee, Dept. Of Obst. And gynae, Era's Lucknow Medical College and Hospital, Lucknow, 226003 Email: sonali.sonam.21@gmail.com. M.0091-7011195693

Correspondence: Dr Fareha Khatoon, Associate Professor, Dept. Of Obstetrics and Gynaecology, Era's Lucknow Medical College and Hospital, Lucknow. Email: faarehak@gmail.com 
care. A lesser rate indicated inadequacy of obstetric care whereas a higher rate implied unnecessary and probably non-indicated management of pregnancies. Recently WHO retracted the earlier statement, emphasising that although they do not recommend a specific rate of $\mathrm{CD}$ any longer, extremely high or low $\mathrm{CD}$ is an important indicator of quality of maternity services of a hospital or a country ${ }^{3}$.

The present study was done as part of our policy to audit the maternity services by finding out the incidence of $\mathrm{CD}$ at our facility and comparing it with the national average. As a secondary outcome measure, we wanted to explore the reasons for high incidence of CD by critical analysis of data as well as by interviewing the primary care providers which included post-graduate students and senior residents.

\section{Methodology}

\section{Design, Setting and Participants:}

The present study is a partially mixed concurrent quantitative and qualitative study. Retrospective analysis of data was conducted at Era's Lucknow Medical College and Hospital, Lucknow (ELMCH) from January 2019 to December 2019. It is a private Medical College that is situated at the outskirts of Lucknow city and has a mixed patient profile, catering to people from middle and lower socio-economic strata of society. The study was approved by the institutional ethical committee. Data extraction was done from Maternity Ward for all women who delivered after 34 weeks of gestation, during the aforementioned period in our facility, including socio-demographic profile, number of births, mode of delivery, reasons for induction of labour and any complications during childbirth. Women who delivered at less than 34 completed weeks of gestation were not included for the purpose of our study. Primigravida was defined as a woman pregnant for the first time. Multigravida was defined as a woman pregnant for $>/=1$ time before the present study. CD was divided in four categories : I - IV as per the NICE guidance ${ }^{4}$. The subjects were divided in two groups depending on whether they had a vaginal delivery (Group II) or CD (Group I). Anonymisation was ensured for the socio-demographic data.

As part of assessment from resident doctors regarding rising trend of $\mathrm{CD}$ and the actual onfloor problems faced by them, the investigators designed and validated a questionnaire consisting of both open- and close-ended questions. The residents were invited to participate in the study and were recruited after prior informed consent and and assurance of anonymity. 21 in depth qualitative interviews were conducted and questionnaire completed.

\section{Main outcomes and measures:}

The CD rate was calculated as the number of CD divided by total births. Each CD were categorised according to Robson's classification ${ }^{5}$ and studied for indication, maternal and perinatal outcome and any intra-partum or postpartum complications for the first 48 hours after CD. The rate for each indication was calculated annually as the number of CD performed for each indication per $100 \mathrm{CD}$.

The results were evaluated in terms of percentage. Statistical analysis was done using Chi square test and calculation of $p$ value. A $p$ value of $<0.05$ was considered as significant.

For the qualitative samples, the questionnaires were coded manually using a coding frame that we developed from the concepts that emerged in the data and taken from existing literature. A list of key themes and sub-themes were drawn up and conclusions drawn.

Ethical issues: The information about patients, their socio-demographic profile was kept strictly confidential.

\section{Results}

A total of 621 deliveries were studied, out of which $44.6 \%$ delivered vaginally and $55.3 \%$ had CD. Table 1 gives the socio-demographic characteristics of the patients recruited for the study. The mean age of subjects was similar in the two groups $\left(\chi^{2}=6.74\right.$; $\mathrm{p}=0.150)$. Majority of women were multigravidas $(66.1 \%)$ and $>/=37$ weeks gestation of pregnancy (85.4\%). 107 women (17.23\%) had prior CD. In this group, $30 \%$ women had more than previous one cesarean. The overall rate of vaginal birth after cesarean (VBAC) was 9.3\%. Repeat CD for women with previous one cesarean and $>$ previous one cesarean being $62.6 \%$ and $96.77 \%$ respectively. 
Table 1: Socio-demographic Profile of Enrolled Patients

\begin{tabular}{|c|c|c|c|}
\hline Characteristic & $\begin{array}{l}\text { Group I } \\
\text { (CD);n(\%) }\end{array}$ & $\begin{array}{l}\text { Group II } \\
\text { (VD);n(\%) }\end{array}$ & Statistics \\
\hline \multicolumn{3}{|l|}{ Age } & \\
\hline$</=19$ years & $11(3.19)$ & $8(2.89)$ & \multirow{5}{*}{$\chi^{2}=6.74 ; p=0.150$} \\
\hline $20-25$ years & $161(48.26)$ & $118(42.60)$ & \\
\hline $26-30$ years & $143(41.56)$ & $112(40.43)$ & \\
\hline $31-35$ years & $20(5.81)$ & $32(11.55)$ & \\
\hline$>35$ years & $9(2.62)$ & $7(2.53)$ & \\
\hline \multicolumn{3}{|l|}{ Parity } & \\
\hline Primigravida & $113(32.8)$ & $98(35.4)$ & \multirow{2}{*}{$\chi^{2}=0.438 ; p=0.508$} \\
\hline Multigravida & $231(67.2)$ & $179(64.6)$ & \\
\hline \multicolumn{3}{|l|}{ Antenatal Status } & \\
\hline Booked & $207(60.2)$ & $151(54.5)$ & \multirow{2}{*}{$\chi^{2}=2.01 ; p=0.156$} \\
\hline Unbooked & $137(39.8)$ & $126(45.5)$ & \\
\hline \multicolumn{3}{|l|}{ Residence } & \\
\hline Urban & $218(63.4)$ & $157(56.7)$ & \multirow{2}{*}{$\chi^{2}=2.87 ; p=0.090$} \\
\hline Rural & $126(36.6)$ & $120(43.3)$ & \\
\hline \multicolumn{3}{|l|}{ Literacy status } & \\
\hline Illiterate & $36(10.5)$ & $34(12.3)$ & \multirow{6}{*}{$\chi^{2}=1.19 ; p=0.946$} \\
\hline Class 6 & $43(12.5)$ & 32 (11.6) & \\
\hline Class $7-10$ & $72(20.9)$ & $52(18.8)$ & \\
\hline Class 11-12 & $136(39.5)$ & $109(39.4)$ & \\
\hline Graduate & $42(12.2)$ & $38(13.7)$ & \\
\hline Post graduate & $15(4.4)$ & $12(4.3)$ & \\
\hline \multicolumn{3}{|c|}{ Socioeconomic status (Kuppuswamy) } & \\
\hline Upper class & $10(2.9)$ & $10(3.6)$ & \multirow{5}{*}{$\chi^{2}=0.563 ; p=0.905$} \\
\hline Upper middle & $108(31.4)$ & $92(33.2)$ & \\
\hline Lower middle & $160(46.5)$ & $125(45.1)$ & \\
\hline Upper lower & $66(19.2)$ & $50(18.1)$ & \\
\hline Lower middle & 0 & 0 & \\
\hline
\end{tabular}

Most of the CD were Category I CD (81.4\%). We have used the Robson system of classification of CD as a standard method for analysis. (Table 2). Overall maximum CD rate was contributed by group 5 of Modified Robson's criteria. (Previous CD, singleton cephalic, $>37$ weeks gestation, before onset of labour).
Table 2: CD Indication According to Modified Robson's Criteria

\begin{tabular}{|c|c|c|c|}
\hline No. & Group & $\mathbf{N}$ & $\%$ \\
\hline 1 & $\begin{array}{l}\text { Nulliparous, singleton cephalic }>37 \\
\text { weeks in spontaneous labour }\end{array}$ & 52 & $15.11 \%$ \\
\hline \multirow[t]{3}{*}{2} & $\begin{array}{l}\text { Nulliparous, singleton cephalic, }>37 \\
\text { weeks, induced or CD before labour }\end{array}$ & & \\
\hline & Induced & 16 & $4.65 \%$ \\
\hline & $\mathrm{CD}$ before labour & 42 & $12.20 \%$ \\
\hline 3 & $\begin{array}{l}\text { Multiparous (excluding previous } \\
\text { CD), singleton cephalic, }>37 \text { weeks in } \\
\text { spontaneous labour }\end{array}$ & 26 & $7.55 \%$ \\
\hline \multirow[t]{3}{*}{4} & $\begin{array}{l}\text { Multiparous (excluding previous CD), } \\
\text { singleton cephalic, }>37 \text { weeks, induced } \\
\text { or CD before labour }\end{array}$ & & \\
\hline & Induced & 7 & $2.03 \%$ \\
\hline & $\mathrm{CD}$ before labour & 30 & $8.72 \%$ \\
\hline \multirow[t]{4}{*}{5} & $\begin{array}{l}\text { Previous CD, singleton cephalic, }>37 \\
\text { weeks }\end{array}$ & & \\
\hline & Spontaneous & 38 & $11.04 \%$ \\
\hline & Induced & 1 & $0.29 \%$ \\
\hline & $\mathrm{CD}$ before labour & 58 & $16.86 \%$ \\
\hline \multirow[t]{4}{*}{6} & All nulliparous breeches & & \\
\hline & Spontaneous & 7 & $2.034 \%$ \\
\hline & Induced & 0 & $0 \%$ \\
\hline & CD before labour & 5 & $1.45 \%$ \\
\hline \multirow[t]{4}{*}{7} & $\begin{array}{l}\text { All multiparous breeches (including } \\
\text { previous CD) }\end{array}$ & & \\
\hline & Spontaneous & 5 & $1.45 \%$ \\
\hline & Induced & 0 & 0 \\
\hline & $\mathrm{CD}$ before labour & 3 & $0.87 \%$ \\
\hline \multirow[t]{4}{*}{8} & $\begin{array}{l}\text { All multiple pregnancies (including } \\
\text { previous CD) }\end{array}$ & & \\
\hline & Spontaneous & 1 & $0.29 \%$ \\
\hline & Induced & 0 & $0 \%$ \\
\hline & $\mathrm{CD}$ before labour & 3 & $0.87 \%$ \\
\hline \multirow[t]{4}{*}{9} & $\begin{array}{l}\text { All abnormal lies (including previous } \\
\text { CD), excluding breech }\end{array}$ & & \\
\hline & Spontaneous & 0 & $0 \%$ \\
\hline & Induced & 0 & $0 \%$ \\
\hline & $\mathrm{CD}$ before labour & 0 & $0 \%$ \\
\hline \multirow[t]{4}{*}{10} & $\begin{array}{l}\text { All single cephalic, }<36 \text { weeks } \\
\text { (including previous CD) }\end{array}$ & & \\
\hline & Spontaneous & 22 & $6.39 \%$ \\
\hline & Induced & 1 & $0.29 \%$ \\
\hline & $\mathrm{CD}$ before labour & 27 & $7.84 \%$ \\
\hline
\end{tabular}

Table 3 gives determinants of mode of delivery. Significant association was found with chronic medical disorders and incidence of CD. 
Table 3: Determinants of Mode of Delivery

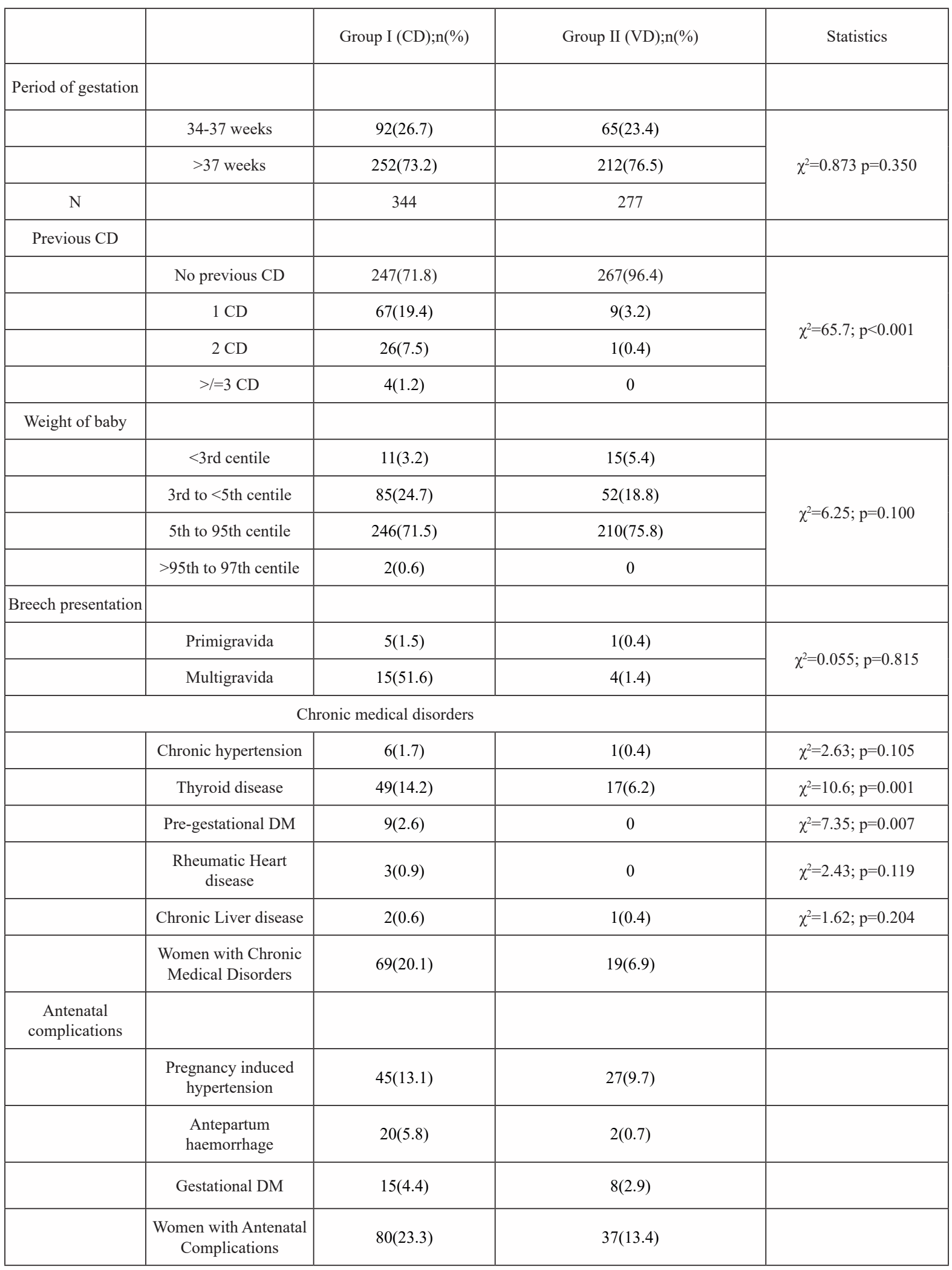

Table 4 tabulates the complications observed with $\mathrm{CD}$ in the present study. Infective sequelae such as minor wound infection, post partum fever and wound gape were the commonest complications. Qualitative Responses of resident doctors are shown in Table 5. 
Table 4: Complications observed with $\mathrm{CD}$ in the present study

\begin{tabular}{|l|l|l|}
\hline \multicolumn{1}{|c|}{ Complication } & Number (n) & $\begin{array}{c}\text { Percentage of } \\
\text { total CD (\%) }\end{array}$ \\
\hline Post partumhaemorrhage & 6 & 1.74 \\
\hline Bladder injury & 0 & 0 \\
\hline Bowel injury & 0 & 0 \\
\hline Wound gape & 11 & 3.20 \\
\hline Urinary tract infection & 6 & 1.74 \\
\hline Wound infection (minor) & 34 & 9.88 \\
\hline Post operative fever & 13 & 3.77 \\
\hline Anaesthetic complications & 3 & 0.87 \\
\hline Total no. of complications & 63 & 18.31 \\
\hline
\end{tabular}

Table 5: Reason for high CD: Responses of Resident Doctors

\begin{tabular}{|c|l|}
\hline 1 & Fear of litigation; early decision for CD \\
\hline 2 & $\begin{array}{l}\text { Non availability of obstetric analgesia, especially in women } \\
\text { with previous CD }\end{array}$ \\
\hline 3 & High risk pregnancies \\
\hline 4 & $\begin{array}{l}\text { Fear of pain of childbirth, especially in women with previous } \\
\text { CD }\end{array}$ \\
\hline 5 & Lack of invasive fetal monitoring \\
\hline 6 & Commercial interests \\
\hline 7 & $\begin{array}{l}\text { Lack of support to patient during labour due to restrictive } \\
\text { policy of not allowing any companion in labour room }\end{array}$ \\
\hline 8 & $\begin{array}{l}\text { Logistical Delays in performing Category I CD, prompting } \\
\text { early decision for CD }\end{array}$ \\
\hline
\end{tabular}

\section{Discussion}

$\mathrm{CD}$ have seen an exponential growth in India in the past ten years. With figures estimating a $300 \%$ increase in incidence ${ }^{6}, \mathrm{CD}$ is attaining the worrisome proportions of an epidemic. Indian government statistics show an increase of $\mathrm{CD}$ in public hospitals, from $6 \%$ of total births in 2008 09 to $14 \%$ in $2018-19^{7}$. The incidence of CD in private hospitals is much higher. ${ }^{8}$

The total CD rate at our institution is $55.3 \%$ which is high and is in concordance with the findings observed by NFHS-4 for the city of Lucknow $^{9}$. Despite the fact that there are no financial remunerations at stake at our Medical College, we find that the CD trend is similar to other private institutions. One of the reasons could be the population demographics and categorisation of cases being practiced in the area, with complicated ones being referred to Medical Colleges. As a result, we find obstetric patients with multiple medical problems and increasing complexity being referred to our institute. Nigar et al ${ }^{10}$ conducted a similar study in Lucknow and found CD rate of $36.39 \%$. They cited a high incidence of referrals as being one of the major factors contributing to $\mathrm{CD}$. We found maternal thyroid disorders, pre-gestational DM and antepartum haemorrhage to be significantly associated with a higher incidence of CD.

UP is amongst the 9 states in India with average CD rates lower than $10 \%$. However, the selfsame states are the highest contributor to maternal and child mortality. Therefore, the lower incidence might actually be a reflection of poor accessibility of essential obstetric care including facilities for indicated CD. The widespread geographic variations in $\mathrm{CD}$ in India have been observed to coincide with under- and over-served regions, lending credence to the hypothesis that this reflects an unmet need for essential obstetric care. ${ }^{11,12}$

Women with previous CD constitute $17.23 \%$ of the study group. $30 \%$ of these women had more than one previous CD. Not only is this a reflection of the increasing number of women with a $\mathrm{CD}$, this is an important contributory factor for rising $\mathrm{CD}$. We found that history of previous $\mathrm{CD}$ is significantly associated with $\mathrm{CD}$ in the index pregnancy. A large majority of subjects in our analysis did not give consent for trial of labour after cesarean (TOLAC). Although we could not assess the reasons for this trend as ours was a retrospective study, other investigators have dealt with this aspect in detail. Fear of pain of childbirth and refusal to undertake any risks such as risk of rupture with TOLAC have been cited as two important reasons. ${ }^{12}$

Information derived from the questionnaire filled by post graduate trainees pertained to the on-site reasons for tilting of obstetric practice towards CD vis-a-vis vaginal delivery (VD). An important reason that emerged was logistical delay in performing Category I CD and resultant adverse perinatal outcome. Due to these concerns, early decision for CD is the norm as opposed to further trial of labor in-spite of latter 
being a legitimate obstetric approach. Gupta et al

${ }^{13}$ found several causes of delay such as obtaining consent, sending investigations, arranging for blood products, non availability of theatre, lack of ancillary staff etc. This needs to be analysed in detail and improvement of processes to be done in order to smoothen the transition of patients from labour ward to theatre.

Limited labour analgesia and fear of pain of VD was a predominant feature especially in primigravidae and in women with previous $\mathrm{CD}$. Aksoy et al ${ }^{14}$ and Stoll et al ${ }^{15}$ observed that fear of labour pain was a major cause behind maternal requests for elective $\mathrm{CD}$. In the context of resource limited settings, provision of epidural analgesia remains restricted. However, other methods of pain relief need to be worked out, including antenatal preparation by conducting education and training sessions for patients and their families. Stoll et al ${ }^{15}$ stated that routine introduction of young women to the relative merits and demerits of $\mathrm{VD}, \mathrm{CD}$ and routine usage of technological and pharmacological interventions will help in empowering them in making the correct decisions during pregnancy and labour.

\section{Limitations of the Study}

Due to the retrospective nature of the present study, there were many aspects that we could not evaluate especially perceptions of patients towards labour and delivery, information about $\mathrm{CD}$ and support available during laboure. e.g presence of birth companion.

\section{Conclusion}

- The incidence of $\mathrm{CD}$ in the present study is $55.3 \%$.

- There is a significant association of maternal thyroid disorders, pre-gestational DM, antepartum haemorrhage and prior history of $\mathrm{CD}$ with a higher incidence of $\mathrm{CD}$.

- The main reasons for high incidence of $\mathrm{CD}$ are high risk pregnancies, previous $\mathrm{CD}$, fear of litigation and logistical delays in performing Category I cesarean section, prompting early decision for $\mathrm{CD}$.

Financial disclosures: None

Conflict of Interest: None

Acknowledgement: None

Justification for Authorship:

AA conceived the project and wrote manuscript, FK defined intellectual content and literature search, SN did data acquisition and analysis, $\mathrm{S}$ and SS helped in statistical analysis. All the authors reviewed the final manuscript. 


\section{References}

1. India Fact Sheet. National Family Health Survey -4 (internet). New Delhi. Ministry of Health and Family Welfare, Government of India. 2015-16. Available from:http://rchiips.org/nfhs/pdf/NFHS4/India.pdf (last accessed on 01.04.2021)

2. Betran AP, Torloni MR, Zhang JJ. Gulmezoglu AM. WHO Statement on Caesarean Section Rates. BJOG. 2016;123(5):667-670. Available from: https://obgyn. onlinelibrary.wiley.com/doi/epdf/10.1111/1471 0528.13526 (last accessed on 01.04.2021)

3. Srivastava S, Chaurasia H, Singh KHJK, Chaudhary P. Exploring the spatial patterns of cesarean section delivery in India: Evidence from National Family Health Survey-4. Clinical Epidemiology and Global Health. 2020 Jun 1;8:414-422. Available from: https://cegh.net/article/S22133984(19)30383-5/fulltext(last accessed on 01.04.2021) https://doi.org/10.1016/j.cegh.2019.09.012

4. National Institute for health and care excellence. Caesarean Section. Clinical Guideline (CG132). 2020; Last updated 4.09.2019. https://www.nice.org. uk/guidance/cg132/resources/caesarean-section-pdf35109507009733(last accessed on 01.04.2021)

5. Robson M, Murphy M, Byrne F. Quality assurance: the 10-group Classification system (Robson classification), induction of labor and cesarean delivery. Int $J$ Gynecol Obstet. 2015;131: S23-27 https://doi.org/10.1016/j.ijgo.2015.04.026

6. Caesarean deliveries have become an 'epidemic' in India - record 300\% jump in last decade - ThePrint. https://theprint.in/health/caesarean-deliveries-havebecome-an-epidemic-in-india-record-300-jump-in-lastdecade/334291/(last accessed on 01.04.2021)

7. Office of the Registrar General \& Census Commissioner, India. Annual Health Survey. Ministry of Home Affairs. Govt. of India. https://main.mohfw.gov.in/documents/ staistics. (last accessed on 01.04.2021)

8. Sabnom R, Islam MZ. Cost and outcome of caesarean section in a public and private hospital in Dhaka city. Bangladesh Journal of Medical Science. July 2013;12(3):276-81. Available from: https://www.banglajol.info/index.php/BJMS/ article/view/15424(last accessed on 01.04.2021) https://doi.org/10.3329/bjms.v12i3.15424 https://doi.org/10.3329/bjms.v12i3.15424 https://doi.org/10.3329/bjms.v12i3.15424

9. State fact Sheet Lucknow Uttar Pradesh. National Family Health Survey-4 (internet). New Delhi. Ministry of Health and Family Welfare, Government of India. 2015-16. Available from: http://rchiips.org/nfhs/FCTS/ UP/UP_Factsheet_157_Lucknow.pdf(last accessed on
01.04.2021)

10. NigarA, Ahmad A, Khan K. A study of rate, indications and maternal morbidity associated with cesarean delivery in a tertiary care hospital.Int $J$ ReprodContraceptObstet Gynecol. $\quad 2019 \quad$ Jul;8(7):2810-2815 https://doi.org/10.18203/2320-1770.ijrcog20193047 https://doi.org/10.18203/2320-1770.ijrcog20193047 https://doi.org/10.18203/2320-1770.ijrcog20193047

11. Galvin G, Hirschhorn LR, Shaikh M, Maji P, Delaney MM, Tuller DE, et al. Availability of Safe Childbirth Supplies in 284 Facilities in Uttar Pradesh, India. Maternal and Child Health Journal 2019 Feb 1;23:240-249. Available from: https://europepmc.org/ article/med/30430350(last accessed on 01.04.2021) https://doi.org/10.1007/s 10995-018-2642-7 https://doi.org/10.1007/s $10995-018-2642-7$ https://doi.org/10.1007/s10995-018-2642-7

12. Panda BK, Nayak I, Mishra US. Determinant of inequality in cesarean delivery in India: A decomposition analysis. Health Care Women Int. 2020 Jul. PMID: 31928373. https://pubmed.ncbi.nlm.nih.gov/31928373/ (last accessed on 01.04.2021)

13. Gupta S, Naithani U, Madanmohan C, Singh A, Reddy P, Gupta A. Evaluation of decision-to-delivery interval in emergency cesarean section: a 1-year prospective audit in a tertiary care Hospital. J AnaesthesiolClinPharmacol. 2017; 33(1): 64-70. Available from: https:// www.joacp.org/article.asp?issn=0970-9185;ye ar $=2017 ;$ volume $=33 ;$ is sue $=1 ;$ spage $=64 ;$ epage $=$ 70;aulast $=\mathrm{Gupta}($ last accessed on 01.04.2021) https://doi.org/10.4103/0970-9185.202197 https://doi.org/10.4103/0970-9185.202197 https://doi.org/10.4103/0970-9185.202197

14. Aksoy M, Aksoy AN, Dostbil A, Celik MG, Ince I. The Relationship between Fear of Childbirth and Women's Knowledge about Painless Childbirth. Obstetrics and Gynecology International. Volume 2014, Article ID 274303. https://www.hindawi.com/ journals/ogi/2014/274303/(last accessed on 01.04.2021) https://doi.org/10.1155/2014/274303 https://doi.org/10.1155/2014/274303 https://doi.org/10.1155/2014/274303

15. Stoll KH, Hauck YL, Down S, Payne D, Hall W, et al. Preference for cesarean section in young nulligravid women in eight OECD countries and implications for reproductive health education Stoll et al. Reprod Health. 2017;14:116. Available from:https://www.ncbi.nlm.nih.gov/pmc/articles/ PMC5594573/(last accessed on 01.04.2021) https://doi.org/10.1186/s12978-017-0354-x https://doi.org/10.1186/s $12978-017-0354-x$ https://doi.org/10.1186/s12978-017-0354-X 